sensitised by means of silver chloride. Fox Talbot's extensive investigations may be said to have laid the foundations of modern photography. The inventor and his work are briefly described in the Photographic Journal (August 1934, pp. 427-435). An exhibition celebrating this centenary of photography is now to be seen at the Gallery of Messrs. Elliott and Fry, Ltd., 63 Baker Street, London. The collection includes a copy of Talbot's book, "The Pencil of Nature", written in 1843, the first book to be illustrated with photographs. Several original prints, including one of Trafalgar Square without the Nelson Monument, and one original paper negative are shown. Talbot was a very close friend of Sir William Herschel, and the early progress of photographic inventions owed much to the suggestions of the latter-notably one made on January 30 , 1839 , that 'hypo' should be used to fix the photographic records.

\section{Biochemical Society, Calcutta}

WITH the object of the promotion of biochemical studies and research, a Biochemical Society has recently been formed at Calcutta. The Society was formally inaugurated on July 6, 1934, at the AllIndia Institute of Hygiene. The first committee of the Society is constituted as follows: Prof. N. M. Basu, Lieut.-Col. T. C. Boyd, Prof. S. Ghosh, Prof. J. N. Mukherjee, Dr. B. B. Sen, Prof. H. K. Sen, Prof. H. E. C. Wilson, with Dr. B. C. Guha as honorary secretary and Dr. B. Ahmad as honorary treasurer. It has been arranged to hold monthly meetings for biochemical discussions and reading of original papers, reviews, etc. Four meetings have already been held.

\section{Vitamin $B_{1}$ Potency of Marmite}

The Marmite Food Extract Co., Ltd., writes, with reference to Mr. A. R. Keast's comments on the vitamin $B_{1}$ potency of its yeast extract (NATURE, Nov. 3, p. 696), that the first estimation which showed a content of 840 international units per oz. has been confirmed in a later test on a mixture of eight different samples. The tests were carried out on pigeons by the method described by Coward, Burn, Ling and Morgan (Biochem. J., 27, p. 1719; 1933). Their letter has been referred to Mr. Keast, who points out that Marmite deteriorates with age, and that the pigeon cure method does not always give the same result as the rat growth method of assaying vitamin $B_{1}$ in terms of the international standard. Coward et al. (loc. cit.) found, for samples of dried yeast, that the pigeon method (cure of head retraction in birds given a diet of polished rice) gave a higher value for the vitamin $B_{1}$ potency than the rat method (growth of rats on a diet deficient solely in vitamin $\left.B_{1}\right)$ : the same results were, however, obtained by both methods in the case of a soft yeast extract. They also point out that although the probable error of the pigeon test is much greater than that of the rat test, yet the former has the great advantage of being specific for the factor it is used to estimate.

\section{Announcements}

Ar the annual dinner of the Institute of Fuel held on November 12, H.R.H. the Duke of Kent presented the Melchett Medal to Dr. Friedrich Bergius, the distinguished German chemist and pioneer in the manufacture of oil from coal. In Germany, Dr. Bergius's hydrogenation process has for several years been used for the production of petrol from brown coal. Methods based on Dr. Bergius's discovery are now being developed in the United States and in Great Britain. At present, Dr. Bergius is working on the production of sugar from wood.

Sir John Cadman has been elected president of the Institution of Petroleum Technologists for the session 1935-36, and will take office immediately after the annual general meeting on March 12, 1935.

THE following officers were elected at the anniversary meeting of the Mineralogical Society on November 1 : President, Sir Thomas Holland; VicePresidents, Mr. Arthur Russell, Sir William Bragg; Treasurer, Mr. F. N. Ashcroft; General Secretary, Mr. W: Campbell Smith; Foreign Secretary, Prof. A. Hutchinson; Editor of the Journal, Dr. L. J. Spencer.

Prof. J. B. S. Haldane, professor of genetics in the University of London, will deliver the tenth annual Norman Lockyer Lecture of the British Science Guild on November 28 at 4.30 p.m. in the Goldsmiths' Hall, London, E.C.2 (by permission of the Goldsmiths' Company), taking as his subject "Human Biology and Its Applications". Tickets, for which there is no charge, are obtainable on application to the Secretary, the British Science Guild, 6, John Street, Adelphi, London, W.C.2.

THE eighth edition of their catalogue of collecting apparatus has been issued by Messrs. Flatters and Garnett, Ltd., 309 Oxford Road, Manchester. The list, which contains a number of new items, includes collecting apparatus for botany, entomology, pond life and geology, besides miscellaneous aquaria, glass top boxes, cabinets and collectors' books.

Applications are invited for the following appointments, on or before the dates mentioned: An assistant lecturer and demonstrator in chemistry at University College, Leicester--The Registrar (Nov. 23). An assistant lecturer in mining at the North Staffordshire Technical College, Stoke-on-TrentThe Clerk to the Governors, Town Hall, Hanley, Stoke-on-Trent (Nov, 26). An assistant inspector of scientific supplies-The Director-General, India Store Department, Belvedere Road, S.E.1 (Nov. 26). A Pender professor of electrical engineering in the University of London (University College)-The Academic Registrar, University of London, S.W.7 (Jan. 18). A chemical engineer for research in waxes -The Secretary, Industrial Research Council, Department of Industry and Commerce, Lord Edward Street, Dublin. 